\title{
Hubungan Antara Umur, Gravida dan Usia Kehamilan Terhadap Resiko Kurang Energi Kronis (KEK) pada Ibu Hamil
}

\author{
Sitti Fatimah ${ }^{1}$, A. Ulfa Fatmasanti ${ }^{2}$ \\ ${ }^{1}$ Akbid Batari Toja Watampone \\ ${ }^{2}$ Akbid Batari Toja Watampone
}

Alamat Korespondensi: (Sittifatimah117@gmail.com/085255420410)

\begin{abstract}
ABSTRAK
Menurut World Health Organization (WHO) jumlah ibu hamil yang mengalami kekurangan energi kronik pada tahun 2016 sebanyak (30,1\%). Pada tahun 2017 jumlah ibu hamil yang mengalami kekurangan energi kronik secara global sebanyak (35-75\%). Tujuan dari penelitian ini adalah untuk mengetahui pengaruh umur, gravida, dan Usia Kehamilan terhadap Resiko kurang energy kronis (KEK) pada ibu hamil. Metode Penelitian cross-sectional ini melibatkan 153 ibu hamil yang periksa selama bulan Januari-Desember 2017 sebagai sampel. Sampel ini dipilih secara acak dengan menggunakan teknik simple random sampling. Pengaruh antar variabel dianalisis menggunakan uji Logistic Regression $(\alpha=0,05)$. Hasil penelitian menunjukkan bahwa umur kurang dari 20 tahun kemungkinan terjadinya Kekurangan Energi Kronis (KEK) 0,118 namun pada umur diatas 35 tahun lebih besar kemungkinan terkenak Kekurangan Energi Kronis (KEK) 0,576 kali dan faktor gravida diketahui bahwa ibu multigravida memiliki kemungkinan 1,021 kali untuk mengalami Kekurangan Energi Kronis (KEK) dibandingkan dengan ibu primigravida, kemudian ibu grandemultigravida juga memiliki kemungkinan 3,200 kali lebih besar untuk mengalami Kekurangan Energi Kronis (KEK) dibandingkan dengan ibu primigravida. Kesimpulan dari penelitian ini adalah terdapat pengaruh umur, primigravida terhadap kejadian Kekurangan Energi Kronis (KEK) pada ibu hamil.
\end{abstract}

Kata Kunci : Gravida, Resiko kurang Energi Kronis Usia Kehamilan, Umur

\section{PENDAHULUAN}

Menurut World Health Organization (WHO) jumlah ibu hamil yang mengalami kekurangan energi kronik pada tahun 2016 sebanyak $(30,1 \%)$. Pada tahun 2017 jumlah ibu hamil yang mengalami kekurangan energi kronik secara global sebanyak (35-75\%). Kejadian kekurangan energi kronik di negara-negara berkembang seperti bangladesh, india, indonesia,myanmar, Nepal, Srilangka dan Thailand adalah adalah (15-47\%) yaitu dengan $\mathrm{BMI},<18,5$. Adapun negara yang mengalami kejadian yang tertinggi adalah bangladesh yaitu $(47 \%)$,sedangkan indonesia merupakan urutan ke empat terbesar setelah india dengan $(35,5 \%)$ dan yang paaling rendah adalah Thaland dengan (15-25\%).

Kekurangan Energi Kronis (KEK) merupakan salah satu masalah yang terjadi pada masa kehamilan dimana tidak seimbangnya antara asupan dengan kebutuhan gizi. Kekurangan energi kronis (KEK) diketahui melalui pengukuran lingkar lengan atas (LILA) ibu yang kurang dari $23,5 \mathrm{~cm}$ atau dibagian pita merah LILA. Akibat yang paling khas dari kejadian Kekurangan Energi Kronis adalah bayi berat lahir rendah (BBLR) dibawah 2500 gram.
Berdasarkan penelusuran penelitian sebelumnya didapatkan hasil bahwa dari 53 ibu hamil, sebanyak 21 ibu hamil $(39,6 \%)$ dalam kategori Kekurangan Energi Kronis dan 32 ibu hamil $(60,4 \%)$ tidak Kekurangan Energi Kronis. Masa kehamilan dimulai dari terjadinya konsepsi sampai dengan lahirnya janin, lamanya kehamilam normal adalah 280 hari (4 mingggu atau 9 bulan 7 hari) yaitu dihitung dari hari pertama haid terakhir. Masa ibu hamil adalah masa dimana seresponden wanita memerlukan unsur gizi yang jauh lebih banyak dari pada yang diperlukan dalam keadaan tidak hamil. Pada ibu hamil yang melakukan pemeriksaan ANC penentuan status gizi dilakukan dengan pelayanan dasar adalah berat badan, tinggi badan dan lingkar lengan atas dibawah $23,5 \mathrm{~cm}$ dinyatakan kekurangan energi kronik yang disebabkan karna ibu mengalami ketidak seimbangan asupan gizi antara energi dan protein sehingga zat gizi yang diperlukan tubuh tdak terpenuhi. Berdasarkan uraian diatas maka, penelitian ini bertujuan untuk mengetahui pengaruh umur, gravida terhadap kejadian Kekurangan Energi Kronis (KEK) pada ibu hamil. 


\section{BAHAN DAN METODE}

Lokasi, populasi, dan sampel

Jenis penelitian ini adalah observasional analitik untuk menganalisis pengaruh umur, gravida, dan usia kehamilan terhadaap kejadian Kekurangan Energi Kronis (KEK). Metode pengukuran dengan cara mengukur Lingkar lengan atas (LILA) dan pada Ibu hamil. Kriteria Kekurangan Energi Kronis (KEK) yaitu $<23,5 \mathrm{~cm}$. Desain penelitian ini adalah cross sectional karena dilakukan pada sekali waktu yaitu pada Bulan Maret 2019 dan data yang diambil merupakan data bulan Januari sampai Desember Tahun 2017 di PKM Paccing. Data yang diambil adalah umur dan gravida ibu hamil. Penentuan besar sampel menggunakan rumus dari Slovin dan didapatkan besar sample adalah 153 ibu hamil. Teknik sampling menggunakan simple random sampling dengan menggunakan tehnik lotre/ undian. Data yang diperoleh kemudian dilakukan analisis menggunakan uji statistic logistic regression.

1. Kriteria inklusi

a. Ibu hamil yang berada di tempat penelitian.

b. Ibu positif hamil

c. Lansia yang tinggal bersama keluarga

2. Kriteria Ekslusi :

a. Ibu hamil yang mengalami gangguan kesehatan

b. Ibu hamil yang tidak koperatif

\section{Pengolahan Data}

1. Selecting

Seleksi merupakan pemilihan untuk mengklarifikasi data menurut kategori.

2. Editing

Editing dilakukan untuk meneliti setiap daftar pertanyaan yang sudah diisi. Editing merupakan kelengkapan pengisian, kesalahan pengisian dan konsistensi dari setiap jawaban.

3. Koding

Koding merupakan tahap selanjutnya dengan memberi kode pada jawaban dari setiap responden.

Analisis data

1. Analisis Univariabel

Analisis univariat dilakukan pada tiap varibel dari hasil penelitian dengan mendiskripsikan setiap variabel penelitian dengan cara membuat tabel distribusi frekuensi pada tiap variabel.

2. Analisis Bivariabel

Analisis bivariat yaitu untuk melihat hubungan antara variabel independen dengan variabel dependen.

\section{HASIL PENELITIAN}

1. Analisis Univariabel

Tabel 1 Distribusi Karakteristik Responden di wilayah kerja puskesmas Paccing. $(n=36)$

\begin{tabular}{|c|l|l|l|l|}
\hline Karakteristik & \multicolumn{1}{|c|}{$\mathrm{n}$} & \multicolumn{1}{c|}{$\%$} & $\mathrm{n}$ & \multicolumn{1}{c|}{$\%$} \\
\hline Umur & & & & \\
$<20$ th & 30 & 83,3 & 98 & 83,8 \\
$20-35$ th & 3 & 8,3 & 2 & 1,7 \\
$>35$ th & 3 & 8,3 & 17 & 14,5 \\
\hline Gravida & & & & \\
Primigravida & 20 & 55,6 & 68 & 58,1 \\
Multigravida & 10 & 27,8 & 22 & 18,8 \\
Grandemulti- & 6 & 16,7 & 27 & 23,1 \\
gravida & & & & \\
\hline Usia & & & & \\
kehamilan & & & & \\
TM I & 20 & 55,6 & 68 & 58,1 \\
TM II & 10 & 27,8 & 22 & 18,8 \\
TM III & 6 & 16,7 & 27 & 23,1 \\
\hline
\end{tabular}

Berdasarkan Pada Tabel 1 Dapat diketahui bahwa ibu hamil yang mengalami Kekurangan Energi Kronis (KEK) sebanyak $(83,3 \%)$ adalah usia kurang dari 20 tahun, sama halnya ibu hamil yang tidak mengalami Kekurangan Energi Kronis (KEK) sebanyak (83,8\%) adalah usia kurang dari 20 tahun. Pada Gravida ibu hamil yang mengalami Kekurangan Energi Kronis (KEK) sebanyak (55,6\%) adalah ibu primigravida, sedangkan ibu hamil yang tidak mengalami Kekurangan Energi Kronis (KEK) sebanyak (18,8\%) adalah ibu multigravida. Sedangkan untuk usia kehamilan, ibu hamil yang mengalami Kekurangan Energi Kronis (KEK) sebanyak $(55,6 \%)$ adalah ibu hamil pada trimester I, sedangkan ibu yang tidak mengalaami Kekurangan Energi Kronis (KEK) sebanyak $(58,1 \%)$ adalah ibu hamil trimester I.

2. Analisis Bivariabel

Tabel 2. Pengujian Signifikansi Parameter Model Regresi Logistik Multivariat untuk kejadian Kekurangan Energi Kronis (KEK).

\begin{tabular}{|c|c|c|c|}
\hline Variabel & OR & $95 \%$ & Sig \\
\hline $\begin{array}{c}\text { Umur } \\
20-35 \text { tahun }\end{array}$ & Ref & & \\
$<20$ tahun & 0,118 & $0,013-1,050$ & 0,150 \\
$>35$ tahun & 0,576 & $0,158-2,102$ & 0,404 \\
\hline $\begin{array}{c}\text { Gravida } \\
\text { Primigravida }\end{array}$ & Ref & & 0,023 \\
Multigravida & 1,021 & $0,175-5,971$ & 0,982 \\
$\begin{array}{c}\text { Grandemultigr } \\
\text { avida }\end{array}$ & 3,200 & $0,517-19,820$ & 0,211 \\
\hline
\end{tabular}


Dari Tabel 2. Dapat kita ketahui bahwa ibu dengan umur kurang dari 20 tahun kemungkinan terjadinya Kekurangan Energi Kronis (KEK) 0,118 tapi namun pada umur diatas 35 tahun lebih besar kemungkinan terkenak Kekurangan Energi Kronis (KEK) 0,576 kali selain itu pada primigravida memiliki pegaruh yang signifikan terhadap kejadian Kekurangan Energi Kronis (KEK). Dari faktor gravida diketahui bahwa ibu multigravida memiliki kemungkinan 1,021 kali untuk mengalami Kekurangan Energi Kronis (KEK) dibandingkan dengan ibu primigravida, kemudian ibu grandemultigravida juga memiliki kemungkinan 3,200 kali lebih besar untuk mengalami Kekurangan Energi Kronis (KEK) dibandingkan dengan ibu primigravida.

\section{PEMBAHASAN}

Hasil penelitian ini sejalan dengan penelitian Rizkah (2017) bahwa umur ibu dan gravida terdapat pengaruh terhadaap terjadinya Kekurangan Energi Kronis (KEK) pada ibu hamil. Kekurangan Energi Kronik (KEK) adalah keadaan dimana ibu menderita keadaan kekurangan kalori dan protein (malnutrisi) yang berlangsung menahun (kronis) yang menyebabkan timbulnya gangguan kesehatan pada wanita usia subur (WUS) dan pada ibu hamil. factor penyebab terjadinya Kekurangan Energi Kronis (KEK) itu di sebabkan beberapa factor, diantaranya hasil penelaian ini dimana ibu hamil yang mengalami Kekurangan Energi Kronis (KEK) pada usia kurang dari 20 tahun dan pada umur 20-35 tahun tidak beresiko terjadinya Kekurangan Energi Kronis (KEK).

Semakin muda dan semakin tua umur seseresponden ibu yang sedang hamil akan berpengaruh terhadap kebutuhan gizi yang diperlukan. Umur muda perlu tambahan gizi yang banyak karena selain digunakan pertumbuhan dan perkembangan dirinya sendiri, juga harus berbagi dengan janin yang sedang dikandung. Sedangkan untuk umur tua perlu energi yang besar juga karena fungsi organ yang melemah dan diharuskan untuk bekerja maksimal, maka memerlukan tambahan energi yang cukup guna mendukung kehamilan yang sedang berlangsung. Sehingga usia yang paling baik adalah lebih dari 20 tahun dan kurang dari 35 tahun, dengan diharapkan gizi ibu hamil akan lebih baik.

Melahirkan anak pada usia ibu yang muda atau terlalu tua mengakibatkan kualitas janin atau anak yang rendah dan juga akan merugikan kesehatan ibu (Baliwati, 2004).
Karena pada ibu yang terlalu muda (kurang dari 20 tahun) dapat terjadi kompetisi makanan antara janin dan ibunya sendiri yang masih dalam masa pertumbuhan dan adanya perubahan hormonal yang terjadi selama kehamilan. Sehingga usia yang paling baik adalah lebih dari 20 tahun dan kurang dari 35 tahun, sehingga diharapkan status gizi ibu hamil akan lebih baik.

Berdasarkan hasil penelitian ini ibu hamil yang mana ibu Grandemultigravida lebih beresiko terkenak Kekurangan Energi Kronis (KEK) dari pada ibu primigravida dan multigravida.gravida merupakan bagian dari penulisan paritas pada ibu hamil. Paritas adalah status seresponden wanita sehubungan dengan jumlah anak yang pernah dilahirkannya. Paritas merupakan salah satu faktor penyebab terjadinya KEK pada ibu hamil. Biasanya ibu dengan paritas lebih dari 5 kali memiliki kemungkinan besar untuk melahirkan bayi BBLR. Ibu yang baru pertama kali hamil merupakan hal yang sangat baru sehingga termotivasi dalam memeriksakan kehamilannya ketenaga kesehatan. Sebaliknya ibu yang sudah pernah melahirkan lebih dari satu responden mempunyai anggapan bahwa ia sudah berpengalaman sehingga tidak termotivasi untuk memeriksakan kehamilannya.

\section{KESIMPULAN}

Kesimpulan dari penelitian ini dari 153 ibu hamil terdapat pengaruh umur dan gravidah terhadap terjadinya Kekurangan Energi Kronis (KEK). Dimana hal ini menunjukkan semakin Tua usia serta seringja mengalami kehamilan maka semakin besar kemungkinan mengalami Kekurangan Energi Kronis (KEK). Saran bagi ibu hamil agar selaalu menjaga kondisi saat hamil dan bagi tenaga kesehatan sebaiknta memberikan konseling secara rutin kepada semua ibu hamil.

\section{SARAN}

1. Ibu hamil diharapkan dapat menjaga kondisi tubuhnya selama proses kehamilan.

2. Puskesmas Batua harus lebih mensosialisasikan kepada ibu hamil terkait dengan bagaimana pencegahan KEK pada ibu hamil.

3. Diharapkan penelitian ini bermanfaat bagi peneliti dan merupakan pengalaman yang sangat berharga dalam melakukan penelitian, serta menambah wawasan peneliti. Bagi peneliti selanjutnya diharapkan untuk memperhatikan variabel lainnya yang berhubungan dengan faktor mempengaruhi KEK. 


\section{DAFTAR PUSTAKA}

Arisman. 2010. Gizi dalam Daur Kehidupan. Buku Ajar Ilmu Gizi. Jakarta: EGC

Adriani, Merryana dan Bambang Wirjatmadi. 2016. Peranan Gizi Dalam Siklus Kehidupan. Jakarta : Prenadamedia Group

Fatimah dan Nuryaningsih. 2017. Asuhan Kebidanan Kehamilan. Jakarta : Fakultas Kedokteran dan Kesehatan Universitas Muhammadiyah Jakarta.

Mochtar, Rustam. 2005. Sinopsis Obsetri. Edisi Ke 6, Jilid 1. EGC: Jakarta

Saraswati. 2003. Risiko Ibu Hamil Kurang Energi Kronis dan Anemia Untuk MelahirkaN Bayi dengan BBLR. Puslitbang Gizi: Jakarta.

Universitas Indonesia. 2007. Buku Pedoman Petunjuk Pelaksanaan Dan Penanggulangan KEK Padalbu Hamil. Fakultas Kesehatan Masyarakat: Jakarta

Who 2016\& jurnal karya ilmiah ilmu kesehatan , 2017 